\title{
PENGARUH PENGORGANISASIAN DAN KOORDINASI TERHADAP KINERJA PEGAWAI PADA KEMENTERIAN AGAMA KABUPATEN OGAN KOMERING ULU TIMUR TIMUR
}

\author{
Wahid Eka Saputra \\ STIE Trisna Negara, Belitang, OKU Timur \\ Email:reksa05@gmail.com
}

\begin{abstract}
Abstrak : Penelitian ini bertujuan untuk mengetahui pengaruh Pengorganisasian dan Koordinasi Terhadap Kinerja Pegawai baik secara simultan (bersama-sama) maupun secara parsial. Hipotesa penelitian ini adalah : 1) Terdapat pengaruh positif dan signifikan antara Pengorganisasian dan Koordinasi secara bersama-sama terhadap Kinerja Pegawai ; 2) Terdapat pengaruh positif dan signifikan antara pengorganisasian dan Kinerja Pegawai ; 3) Terdapat pengaruh positif dan signifikan antara koordinasi terhadap Kinerja pegawai. Penelitian ini dilaksanakan pada Kementerian Agama Kabupaten Ogan Komering Ulu Timur dengan metode penelitian survey sampel. Responden penelitian adalah pegawai Kementerian Agama Kabupaten Ogan Komering Ulu Timur yang berjumlah 39 orang. Instrument yang digunakan adalah kuisioner mengenai Pengorganisasian dan Koordinasi sebagai variabel bebas (Independent Variabel), dan kuisioner mengenai Kinerja Pegawai sebagai variabel terikat (Dependent Variabel). Instrument kuisioner Pengorganisasian dan Koordinasi kerja divalidasi dengan rumus Korelasi Pearson Product Moment, sedangkan Realibilitas Instrument diukur dengan Alpha Cronbach. Analisa data menggunakan Analisa Regresi Sederhana, Regresi Berganda, dan Koefisien Determinasi $\left(\mathrm{R}^{2}\right)$. Uji-F untuk mengetahui pengaruh dari kedua variabel bebas Pengorganisasian dan Koordinasi secara simultan terhadap Kinerja pegawai. Sedangkan Uji-t digunakan untuk mengetahui pengaruh kedua variabel bebas Pengorganisasian dan Koordinasi secara parsial dengan Kinerja pegawai sebagai variabel terikat. Taraf signifikansi yang digunakan pada penelitian ini adalah $\mathrm{a}=5 \%$. Dari hasil penelitian ditemukan bahwa ; (1) secara simultan terdapat pengaruh yang signifikan antara variabel bebas Pengorganisasian dan Koordinasi terhadap variabel terikat Kinerja pegawai dimana korelasi (R) sebesar 0.875 , (2) secara parsial terhadap pengaruh yang signifikan antara pengorganisasian terhadap Kinerja pegawai, dimana koefisien korelasi sederhana (r) sebesar 0.819, (3) Secara Parsial terdapat pengaruh yang positif antara koordinasi terhadap Kinerja pegawai dimana koefisien korelasi sederhana (r) sebesar 0.817.
\end{abstract}

Kata Kunci : Pengorganisasian, Koordinasi, Kinerja

\section{PENDAHULUAN}

Seiring dengan arus era globalisasi maka metode-metode pengembangan pegawai harus menyesuaikan dan tepat sasaran, agar pegawai dapat berkembang sesuai dengan kebutuhan.

Kondisi diatas dalam era reformasi sekarang ini menuntut pemerintah agar dapat memberikan pelayanan yang berkualitas dari abdi negara dan abdi masyarakat yang menjadi sorotan yang luas, banyak masyarakat yang menaruh perhatian rendahnya penilaian dari masyarakat akan pentingnya kinerja pelayanan yang diberikan oleh pegawai negeri.

Pegawai Negeri sebagai unsur aparatur negara dan abdi masyarakat; mempunyai peran yang amat penting dalam rangka menciptakan masyarakat madani yang taat hukum, berperadaban modern, demokratis, makmur, adil, dan bermoral tinggi yang 
menyelenggarakan pelayanan secara adil dan merata, menjaga persatuan dan kesatuan bangsa dengan penuh kesetiaan kepada Pancasila dan Undang Undang Dasar Tahun 1945 (Suradji : 2003 : 4). Yang kesemuanya itu adalah dalam rangka mencapaian tujuan yang dicita-citakan bangsa Indonesia. Untuk dapat melaksanakan tugas tersebut diperlukan Pegawai Negeri yang berkemampuan melaksanakan tugas secara profesional dan bertanggung jawab dalam menyelenggarakan tugas pemerintahan dan pembangunan, serta bersih dan bebas dari korupsi dan nepotisme.

Organisasi dapat dipandang sebagai wadah atau tempat orang saling bekerja sama dalam melaksanakan kegiatan-kegiatan dalam rangka pencapaian tujuan yang telah ditetapkan sebelumnya. Organisasi juga dipandang sebagai saluran hierarki kedudukan atau jabatan yang ada menggambarkan secara jelas wewenang garis komando, dan garis tanggung jawab juga bisa disebut garis koordinasi. Perkembangan lingkungan eksternal Organisasi termasuk didalamnya kemajuan teknologi, maka terjadi spesialisasi bidang pekerjaan dalam unit organisasi serta keahlian yang dimiliki individu. Untuk mencapai organisasi perlu adanya koordinasi karena koordinasi adalah salah satu prinsip dari organisasi atau dengan perkataan lain sebagai jalan untuk mencapai suatu kondisi yang diinginkan. Tujuan organisasi yang telah ditetapkan adalah suatu kondisi yang telah disepakati oleh semua anggota organisasi.

Dengan demikian tujuan organisasi dapat dicapai jika semua anggota organisasi yang mempunyai kesediaan untuk bekerjasama dan kegiatan mereka dapat dikoordinir dengan baik, agar tidak terjadi kesimpang siuran dan tumpang tindih atau kekosongan serta kehampaan tindakan dalam pekerjaan. Dengan kata lain prinsip yang harus menjadi landasan dari semua kerjasama adalah koordinasi. Jelaslah bahwa koordinasi sangat penting dilakukan, dalam suatu organisasi kerjasama yang baik dalam mekanisme kerja sangat tergantung pada hubungan timbal balik antar pimpinan dengan para staf maupun sesama pegawai. Kegiatan koordinasi berlaku untuk semua unit pekerjaan, dimana tiap-tiap unit pekerjaan yang dilakukan oleh berbagai orang dapat berlangsung dengan serasi dan seimbang ke arah yang diinginkan, maka seorang pimpinan harus dapat melaksanakan suatu tindakan koordinasi. Sehubungan dengan itu seorang pimpinan bukan lagi sekedar pemimpin suatu organisasi melainkan sebagai pejabat yang berkedudukan sebagai anggota penuh pimpinan organisasi yang peranannya sama pentingnya dengan pejabat pimpinan dalam berbagai bidang kerja lainnya. Pimpinan harus menunaikan tugasnya untuk mencapai Kinerja pegawai. Karena kinerja adalah ukuran dalam upaya mencapai tujuan organisasi yang telah ditentukan sebelumnya.

Pada Kementerian Agama Kabupaten Ogan Komering Ulu Timur belum menunjukkan kinerja sebagai mana yang diharapkan, ini disebabkan kurangnya koordinasi dari pimpinan terhadap staf, kurangnya kerjasama yang baik antara anggota unit organisasi dan staf dalam organisasi, kurang lancaraya komunikasi antara pimpinan dan staf. Sekretaris selaku pemimpin anggota organisasi tidak lepas kaitannya dengan aktivitas-aktivitas para pegawai yang perlu diatur dan disusun sebaik-baiknya. Hal ini berkaitan dengan terdapatnya unit-unit organisasi maupun individu yang mempunyai fungsi yang berbeda dalam rangka penyelenggaraan organisasi secara keseluruhan.

Apabila pimpinan dapat melaksanakan koordinasi internal dengan baik maka kinerja pegawai akan tercapai. Lebih jelasnya pimpinan yang melakukan koordinasi dengan baik akan mempunyai pengaruh yang besar dalam peningkatan kinerja pegawai sehingga akan menunjang tercapainya tujuan organisasi. Melalui koordinasi (dalam hal ini koordinasi internal), seluruh kegiatan organisasi dapat diatur, diselenggarakan dan dibina agar kegiatan tiap individu dalam struktur organisasi yang ada, tercapai secara optimal yaitu berupa kinerja secara keseluruhan. 
Dengan memperhatikan uraian-uraian tersebut diatas, maka dalam penelitian ini penulis tertarik mengangkat judul "Pengaruh Pengorganisasian dan Koordinasi Terhadap Kinerja Pegawai pada Kementerian Agama Kabupaten Ogan Komering Ulu Timur".

\section{KAJIAN TEORI}

\section{Pengertian Manajemen Sumber Daya Manusia}

Manajemen Sumber Daya Manusia adalah suatu proses menangani berbagai masalah pada ruang lingkup karyawan, pegawai, buruh, manajer dan tenaga kerja lainnya untuk dapat menunjang aktifitas organisasi atau perusahaan demi mencapai tujuan yang telah ditentukan. Bagian atau unit yang biasanya mengurusi SDM adalah departemen sumber daya manusia atau dalam Bahasa Inggris disebut HRD atau Human Resource Departement.

Menurut A.F. Stoner manajemen sumber daya manusia adalah suatu prosedur yang berkelanjutan yang bertujuan untuk memasok suatu organisasi atau perusahaan dengan orangorang yang tepat untuk ditempatkan pada posisi dan jabatan yang tepat pada saat organisasi memerlukannya. Departemen Sumber Daya Manusia memiliki Peran, Fungsi, Tugas dan Tanggung

\section{Pengorganisasian}

Suatu perusahaan atau badan usaha baik besar maupun kecil memerlukan organisasi yang disesuaikan dengan jenisnya. Adanya organisasi yang baik, tentu akan membantu manajemen dalam memperlancar kerja sama antar bagian dalam menjelaskan hubungan kerja antar bagian dalam menjelaskan hubungan kerja antara bagian yang satu dengan yang lain sehingga menimbulkan keteraturan dan keserasian dalam menjalankan aktivitas perusahaan. Adapun pengertian pengorganisasian menurut Drs. Malayu S.P. Hasibuan (2011 : him. 118) adalah:

"Suatu proses penentuan, pengelompokan dan pengaturan bermacam-macam aktivitas yang diperlukan untuk mencapai tujuan, menempatkan orang-orang pada setiap aktivitas ini, menyediakan alat-alat yang diperlukan, menetapkan wewenang yang secara relative didelegasikan kepada setiap individu yang akan melakukan aktivitas tersebut".

Sedangkan menurut Sarwoto pengorganisasian adalah:

"Keseluruhan proses pengelompokan orang-orang, alat, tugas dan tanggung jawab atau wewenang sedemikian rupa sehingga tercipta suatu organisasi yang dapat digerakkan sebagai satu kesatuan dalam rangka mencapai tujuan yang telah ditetapkan".

Sesuai dengan teori-teori yang dikemukakan oleh para ahli tersebut nampak jelas bahwa pengorganisasian adalah kegiatan-kegiatan yang dilakukan seorang pimpinan atau manajer dalam suatu organisasi atau perugahaan untuk mencapai tujuan yang diinginkan.

Dengan demikian maka dapat ditarik kesimpulan bahwa pengorganisasian memang sangatlah penting bag! suatu pekerjaan atau aktivitas untuk mencapai tujuannya dan memperoleh hasil yang efektif dan efisien bagi organisasi tersebut.

Adapun Pengertian organisasi menurut Sondang P. Siagian, (2011 : Him. 121) adalah : "Sekelompok orang yang terikat secara formal dan hirarki serta bekerja sama untuk mencapai tujuan tertentu yang telah ditetapkan sebelumnya".

Sedangkan menurut Malayu SP. Hasibuan, (2010 : Him. 05) organisasi adalah : "Suatu sistem perserikatan formal, berstruktur dan terkoordinasi dari sekelompok orang yang bekerja sama dalam mencapai tujuan tertentu". Jadi pengertian organisasi itu sendiri adalah keseluruhan dari komponen-komponen dan posisi kegiatan kerja baik yang bersifat manusia 
maupun non manusia yang dapat dikelompokkan dalam tugas, wewenang dan tanggung jawab sehingga terdapat suatu kesatuan untuk mencapai tujuan tertentu yang telah ditentukan.

\section{Koordinasi}

Didalam melaksanakan suatu pekerjaan harus ada keselarasan antara orang-orang dan pekerjaannya agar dapat mencapai tujuan tertentu. Jadi dalam hal ini mengkoordinasikan semua unsur manajemen biasanya dirumuskan dengan $6 \mathrm{~m}$.

Menurut Malayu SP. Hasibuan (2001 : Him. 21) unsur-unsur manajemen terdiri dari:

1) Man,

Tenaga manusia, baik tingkat eksekutif maupun operatif.

2) Money

Uang yang dibutuhkan untuk mencapai tujuan yang diinginkan.

3) Methode

Cara-cara yang digunakan untuk mencapai tujuan.

4) Materials

Bahan-bahan yang diperlukan untuk mencapai tujuan.

5) Machine

Adapun definisi koordinasi menurut G.R Terry dikutip dari buku karangan Malayu SP. Hasibuan (200 : Him. 86) "Suatu usaha yang sinkron/teratur untuk menyediakan jumlah dan waktu yang tepat, dan mengarahkan pelaksanaan untuk menghasilkan suatu tindakan yang seragam dan harmonis pada sasaran yang telah ditentukan'. Dari definisi tersebut dapat disimpulkan bahwa koordinasi mempunyai arti pernyataan manusia dan meliputi:

1) Jumlah usaha baik secara kualitatif maupun kuantitatif.

2) Waktu yang tepat dari usaha ini.

3) Penentuan arah usaha-usaha ini. Sedangkan pengertian koordinasi menurut Awaludin Djamin yang dikutip dari buku karangan Malayu S.P Hasibuan (200 : Him. 86) " Suatu usaha kerja sama antar badan, instansi, unit dalam pelaksanaan tugas-tugas tertentu sedemikian rupa, sehingga saling mengisi, saling membantu dan saling melengkapi".

\section{Kinerja}

Setiap Dinas atau instansi akan selalu berusaha agar kinerja dari para pegawai dapat ditingkatkan. Untuk itu peyelidikan waktu dan gerak dari para pegawai sangat diperlukan, yaitu dengan jalan mempelajari gerak-gerik ini, mengubah gerak yang tidak perlu dan melelahkan dengan gerak-gerik baru yang dapat mengurangi kelelahan dan mempercepat selesainya pekerjaan.

Tetapi hal ini tidak menjamin karena semua terletak pada pegawai itu sendiri apakah ia bekerja dengan sepenuh hati atau tidak. Untuk dapat meningkatkan produktivitas lebih tinggi lagi, instansi perlu menimbulkan kinerja dari para pegawai.

Oleh karena itu sudah sewajarnya bila setiap instansi akan selalu berusaha agar para pegawai mempunyai moral kerja yang tinggi, sebab dengan moral kerja yang tinggi diharapkan kinerja akan dapat meningkat. Manajemen merupakan pengembangan manusia, bukan benda. Sebagai suatu fungsi manajemen, maka perribinaan harus bersifat membimbing dan mendidik pegawai tersebut untuk' meningkatkan kemampuannya dalam melakukan tugastugas yang dilaksanakannya. Untuk mengukur keberhasilan pembinaan, dapat dilihat dari kinerja pegawai. Pengertian kinerja menurut Iskandar (2005 : 102) adalah : "Suatu kemampuan dan keahlian seseorang dalam memahami tugas dan fungsinya dalam bekerja". Sedangkan Mangkunegara (2000 : 67) berpendapat bahwa yang dimaksud dengan kinerja 
(prestasi kerja) adalah : "Hasil kerja secara kualitas yang dicapai oleh seorang pegawai dalam melaksanakan tugasnya sesuai dengan tanggungjawab yang diberikan kepadanya".

\section{METODOLOGI PENELITIAN}

\section{Tempat dan Waktu Penelitian}

Penelitian ini dilakukan pada Kementerian Agama Kabupaten Ogan Komering Ulu Timur selama 3 (tiga) bulan dari November 2018 sampai dengan Februari 2019 Penelitian ini diharapkan dapat memberikan masukan dan manfaat dalam hal pengorganisasian dan koordinasi terhadap kinerja pegawai pada Kementerian Agama Kabupaten Ogan Komering Ulu Timur.

\section{Populasi dan Sampel}

Menurut Sugiyono (200: 72) populasi adalah wilayah generalisasi yang terdiri atas objek atau subjek yang mempunyai kualitas dan karakteristik tertentu yang ditetapkan oleh peneliti untuk dipelajari kemudian ditarik kesimpulan. Populasi dalam penelitian ini adalah seluruh pegawai yaitu 39 pegawai yang akan dijadikan responden. Yang menjadi responden adalah 39. pegawai.

Sampel adalah bagian dari jumlah dan karakteristik yang dimiliki oleh populasi. Prosedur penarikan sampel menggunakan metode sensus artinya seluruh populasi yang ada digunakan sebagai sampel penelitian.

\section{HASIL PENELITIAN DAN INTERPRETASI}

\section{Uji Hipotesis Statistik}

Hipotesis Pertama : Diduga terdapat pengaruh Pengorganisasian (XI) dan Koordinasi (X2) secara bersama-sama Terhadap Kinerja Pegawai

Hipotesis pertama yang diajukan dalam penelitian ini menyatakan bahwa diduga terdapat pengaruh antara Pengorganisasian dan Koordinasi terhadap Kinerja Pegawai pada Kementerian Agama Kabupaten Ogan Komering Ulu Timur.

Berdasarkan hasil perhitungan ternyata hasil uji Sig. F > 0.05, karena taraf signifikansi lebih dari 0.05 maka dapat disimpulkan pada tingkat kepercayaan 95\% HO ditolak atau Hipotesis pertama diterima, artinya secara bersama-sama Pengorganisasian dan Koordinasi bisa menjelaskan skor Kinerja Pegawai. Dengan kata lain, makin tinggi Pengorganisasian dan Koordinasi secara bersama-sama yang diterapkan pegawai Kementerian Agama Kabupaten Ogan Komering Ulu timur makin tinggi pula Kinerja Pegawai yang diperlihatkan oleh pegawai. Sebaliknya, makin rendah Pengorganisasian dan Koordinasi secara bersama-sama yang diterapkan oleh pegawai maka makin rendah pula kinerja yang diperlihatkan oleh pegawai tersebut.

Hipotesis Kedua : Diduga terdapat pengaruh Pengorganisasian (Xi) Terhadap Kinerja Pegawai (Y)

Hipotesis kedua yang diajukan dalam penelitian ini menyatakan bahwa diduga terdapat pengaruh antara Pengorganisasian terhadap Kinerja Pegawai pada Kementerian Agama Kabupaten Ogan Komering Ulu timur.

Berdasarkan hasil perhitungan ternyata hasil uji sig. $\mathrm{t}>0.05$, karena taraf signifikansi lebih dari 0.05 maka dapat disimpulkan pada tingkat kepercayaan 95\% HO ditolak atau Hipotesis kedua diterima, artinya Pengorganisasian bisa menjelaskan skor Kinerja Pegawai. 
Dengan kata lain, makin tinggi pengorganisasian yang diterapkan oleh pegawai Kementerian Agama Kabupaten Ogan Komering Ulu Timur makin tinggi pula Kinerja yang diperlihatkan oleh pegawai. Sebaliknya, makin rendah pengorganisasian yang diterapkan oleh pegawai maka makin rendah pula Kinerja yang diperlihatkan pegawai tersebut.

Hipotesis Ketiga : Diduga terdapat pengaruh Koordinasi (X2) Terhadap Kinerja Pegawai (Y) Hipotesis ketiga yang diajukan dalam penelitian ini menyatakan bahwa diduga terdapat pengaruh antara Koordinasi terhadap Kinerja Pegawai Kementerian Agama Kabupaten Ogan Komering Ulu Timur.

Berdasarkan hasil perhitungan ternyata hasil uji sig. $\mathrm{t}>0.05$, karena taraf signifikansi lebih dari 0.05 maka dapat disimpulkan pada tingkat kepercayaan 95\% HO ditolak atau Hipotesis ketiga diterima, artinya Koordinasi bisa menjelaskan skor Kinerja Pegawai. Dengan kata lain, makin tinggi Koordinasi yang diterapkan pada pegawai Kementerian Agama Kabupaten Ogan Komering Ulu Timur makin tinggi pula Kinerja Kerja yang diperlihatkan oleh pegawai. Sebaliknya, makin rendah Koordinasi yang diterapkan oleh pegawai maka rendah pula Kinerja Pegawai yang diperlihatkan oleh pegawai tersebut.

\section{Interprestasi}

Sesuai dengan analisis regresi berganda dan korelasi antara Pengorganisasian dan Koordinasi secara bersama-sama terhadap Kinerja Pegawai menunjukkan model regresi $\mathrm{Y}=$ $0.776+0.523 \mathrm{XI}+0.467 \mathrm{X} 2+\mathrm{e}$ dengan koefisien korelasi sebesar 0.875 pada taraf kepercayaan 95\% diperoleh pengertian bahwa Pengorganisasian dan Koordinasi secara simultan dapat memprediksi Kinerja Pegawai. Pengorganisasian dan Koordinasi secara simultan memiliki pengaruh yang positif yang erat dengan Kinerja Pegawai sebesar $75.3 \%$ memiliki pengaruh yang berarti. Pengaruh Pengorganisasian dan Koordinasi secara bersamasama simultan terhadap Kinerja Pegawai Pada Kementerian Agama Kabupaten Ogan Komering Ulu Timur adalah sebesar 0.776, maka apabila terdapat peningkatan pada Pengorganisasian dan Koordinasi secara bersama-sama maka hal tersebut akan meningkatkan Kinerja Pegawai Pada Kementerian Agama Kabupaten Ogan Komering Ulu Timur dengan signifikan.

Hasil deskriptif pada variabel Kinerja Pegawai menunjukkan bahwa Kinerja Pegawai pada Kementerian Agama Kabupaten Ogan Komering Ulu Timur memiliki skor rata-rata 3.87 dan masuk dalam kategori baik karena berada pada (Interval 3 - 4), artinya Kinerja Pegawai pada Kementerian Agama Kabupaten Ogan Komering Ulu Timur sudah menunjukkan hasil yang baik dan cukup optimal

Berdasarkan hasil deskriptif analisis butir variabel Pengorganisasian dapat diketahui bahwa Pengorganisasian pada Kementerian Agama Kabupaten Ogan Komering Ulu Timur memiliki skor rata-rata 3.87 dan berada pada kategori baik (Interval 3 - 4), artinya Pengorganisasian sudah baik dan cukup optimal. Hasil ini mengindikasikan Pengorganisasian sudah baik.

Hasil analisis regresi dan korelasi antara Pengorganisasian terhadap Kinerja Pegawai menunjukkan model regresi $\mathrm{Y}=0.776+0.523 \mathrm{X}_{1}+\mathrm{e}$ dengan koefisien korelasi sebesar 0.819 pada taraf kepercayaan $95 \%$ diperoleh pengertian bahwa Pengorganisasian dapat memprediksi Kinerja Pegawai. Pengorganisasian memiliki pengaruh yang positif dengan Kinerja Pegawai sebesar $66.2 \%$ dan memiliki pengaruh yang berarti. Pengaruh Pengorganisasian terhadap Kinerja Pegawai pada Kementerian Agama Kabupaten Ogan Komering Ulu Timur menunjukkan bahwa bila terdapat peningkatan sebesar $1 \%$ pada Pengorganisasian maka secara signifikan akan meningkatkan Kinerja Pegawai sebesar 66.2\%. 
Berdasarkan hasil deskriptif analisis butir variabel Koordinasi dapat diketahui bahwa Koordinasi pada Kementerian Agama Kabupaten Ogan Komering Ulu Timur memiliki skor rata-rata 3.61 dan berada pada kategori baik (Interval 3 -4), artinya Koordinasi sudah baik dan cukup optimal. Hasil ini mengindikasikan bahwa Koordinasi sudah baik.

Hasil analisis regresi dan kolerasi antara Koordinasi Terhadap Kinerja Pegawai menunjukkan model regresi $\mathrm{Y}=8.770+0.823 \mathrm{X}_{2}+$ e dengan koefisien korelasi sebesar 0.817 pada taraf kepercayaan 95\% diperoleh pengertian bahwa Koordinasi dapat mempredikasi Kinerja Pegawai. Koordinasi memiliki pengaruh yang positif dengan Kinerja Pegawai pada Kementerian Agama Kabupaten Ogan Komering Ulu Timur menunjukkan bahwa bila terdapat peningkatan sebesar $1 \%$ pada Koordinasi maka secara signifikan akan meningkatkan Kinerja Pegawai sebesar $65.8 \%$.

Hasil analisis regresi linear sederhana pada masing-masing variabel bebas menunjukkan kedua variabel bebas ini secara individu memiliki pengaruh yang positif serta pengaruh signifikan terhadap Kinerja Pegawai pada Kementerian Agama Kabupaten Ogan Komering Ulu Timur.

Hasil penelitian membuktikan bahwa Pengorganisasian dan Koordinasi merupakan faktor yang memiliki pengaruh yang signifikan baik secara individu maupun secara bersama-sama terhadap Kinerja Pegawai. Semakin baik Pengorganisasian dan Koordinasi, maka akan semakin tinggi Kinerja Pegawai, begitu juga sebaliknya semakin rendah Pengorganisasian dan Koordinasi maka akan semakin rendah Kinerja Pegawai pada Kementerian Agama Kabupaten Ogan Komering Ulu Timur

\section{KESIMPULAN, IMPLIKASI DAN SARAN Kesimpulan}

Berdasarkan hasil analisis dan interprestasi yang telah dilakukan pada bab sebelumnya, maka dapat ditarik kesimpulan antara lain sebagai berikut:

1) Terdapat pengaruh yang erat dan signifikan antara Pengorganisasian $\left(X_{1}\right)$ dan Koordinasi $\left(\mathrm{X}_{2}\right)$ secara bersama-sama terhadap Kinerja Pegawai pada Kementerian Agama Kabupaten Ogan Komering Ulu Timur sebesar 75.3\%, yang berarti Kinerja Pegawai dapat dijelaskan oleh variabel Pengorganisasian dan Koordinasi secara bersama-sama sebesar 75.3\%.

2) Terdapat pengaruh positif dan signifikan antara Pengorganisasian $\left(X_{1}\right)$ terhadap Kinerja Pegawai pada Kementerian Agama Kabupaten Ogan Komering Ulu Timur. sebesar 0.662 yang berarti Kinerja Pegawai dapat dijelaskan oleh variabel Pengorganisasian sebesar $66.2 \%$.

3) Terdapat pengaruh positif dan signifikan antara Koordinasi $\left(X_{2}\right)$ terhadap Kinerja Pegawai pada Kementerian Agama Kabupaten Ogan Komering Ulu Timur sebesar 0.658 yang berarti Kinerja Pegawai dapat dijelaskan oleh variabel Koordinasi sebesar 65.8\%.

4) Variabel Pengorganisasian mempunyai pengaruh yang lebih dominan terhadap Kinerja Pegawai pada Kementerian Agama Kabupaten Ogan Komering Ulu Timur dibandingkan dengan variabel Koordinasi. Sehingga untuk mewujudkan Kinerja Pegawai yang optimal, maka yang lebih dahulu ditingkatkan adalah variabel Koordinasi.

\section{Implikasi}

Untuk meningkatkan Kinerja Pegawai dapat dilakukan dengan upaya peningkatan variabel Pengorganisasian dan Koordinasi. Berikut ini upaya peningkatan variabel 
Pengorganisasian dan Koordinasi yang pada gilirannya dapat meningkatkan efektivitas kerja pegawai yaitu:

1) Pengorganisasian sangatlah penting bagi suatu pekerjaan atau aktivitas untuk mencapai tujuannya dan memperoleh hasil yang efektif dan efisien bagi organ isasi tersebut. Maka dapat dikatakan bahwa jika Pengorganisasian baik maka organisasipun akan berjalan lancar dan tujuan mudah dicapai.

2) System Koordinasi kerja pegawai tidak dapat diperintah, dipaksakan oleh karena itu lebih baik dilakukan dengan cara permintaan, pemahaman, kepada pegawai karena dengan cara ini akan lebih mudah diresapi, ditaati oleh para pegawai serta mereka merasa lebih dihargai.

\section{Saran}

Berdasarkan kesimpulan hasil penelitian seperti yang diuraikan sebelumnya, maka pada bagian berikut perlu diberikan saran pada pihak-pihak yang terkait dengan penelitian ini.

1) Bagi pegawai pada Kementerian Agama Kabupaten Ogan Komering Ulu Timur, agar dapat meningkatkan efektivitas kerjanya secara optimal khususnya dalam melaksanakan tugas sesuai persyaratan tekhnis serta mampu meningkatkan kreatifitas dalam dirinya.

2) Bagi Pimpinan Kementerian Agama Kabupaten Ogan Komering Ulu Timur disarankan agar dapat memperhatikan pemberian pemberian Koordinasi dan Pengorganisasian yang tepat bagi pegawai.

3) Bagi Akademis, penelitian ini dapat menjadi salah satu informasi untuk menambah ilmu pengetahuan, khususnya yang berkaitan dengan pemberdayaan Sumber Daya Manusia dalam upaya mewujudkan Kinerja Pegawai yang lebih optimal melalui Pengorganisasian dan Koordinasi.

\section{DAFTAR PUSTAKA}

Arikunto, Suharsimi. 1998. Prosedur Penelitian. Rineka Cipta. Jakarta.

Garaika. 2010. Pedoman Penyusunan Tests MM - STIE Trisna Negara. Program Pascasarjana STIE Trisna Negara.

Hadiwiryo, B. Siswanto Sastro. 2002. Manajemen Tenaga Kerja Manusia. BumiAksara. Bandung.

Haiman. 2000. Pengertian Manajemen. PT.Gramedia. Jakarta. Handoko, T. Hani. 2001. Manajemen

Personalia. Bumi Aksara. Jakarta. Hasibuan, S.P. Malayu. 2001. Manajemen Sumber Daya Manusia.

BumiAksara. Jakarta. Manullang. 1981. Manajemen Personalia. Ghalia Indonesia. Jakarta. Nitisemito,

S. Alex. 1992. Manajemen Personalia. Ghalia Indonesia. Jakarta.

Ranupandojo, Heidjrachman dan Saud Husnan. 2002. Manajemen Personalia. BPFE. Yogyakarta. Siagian, $\quad$ P. Sondang. 1991. Manajemen Sumber Daya Manusia. 
BumiAksara. Jakarta. Stoner, F. James. 1996. Manajemen. Prenhanlindo. Jakarta. Sugiyono. 1999. Mentodologi Penelitian

Bisnis. Alfabeta. Bandung. Terry, GR. 1991. Prinsip - Prinsip Manajemen. BinaAksara. Jakarta. Toha, Miftah 1999. Kepemimpinan Dalam Manajemen. CV. Rajawali.

Jakarta. Umar, Husein. 1998. Study Kelayakan Bisnis. Gramedia Pustaka Utama. Jakarta.

Handoko, T.Hani. 2004. Manajemen. Yogyakarta: penerbit BPFE UGM.

Cetakan ke-Delapanbelas.

Mangkunegara Anwar Prabu. 2007. Evaluasi Kinerja Sumber daya manusia. Bandung: PT Refika Aditama. 9 Malayu, SP. Hasibuan. 2009. Manajemen Dasar, Pengertian, dan Masalah.

Jakarta: Bumi Aksara. Pasolong, Harbani. 2010. Teori Administrasi Publik.

Makassar: Alfabeta. Solihin, Ismail. 2009. Pengantar Manajemen. Jakarta: Erlangga.

Sutrisno, Edy. 2011. Manajemen Sumber Daya Manusia. Jakarta: Kencana.

Syafruddin. 2003. Relationship Marketing : Inovasi Pemasaran yang Membuat Pelanggan Bertekuk Lutut. Jakarta : PT. Gramedia Pustaka Utama.

Danim, Sudarwan. 2004. Motivasi Kepemimpinan dan Efektivitas Kelompok. Bengkulu: PT Rineka cipta.

Djarwanto,dkk. 2003. Statistik Induktif. Yogyakarta: BPFE

Foster, Bill. 2001. Pembinaan untuk Peningkatan Kinerja Karyawan. Jakarta: PPM. G.R Terry dalam

Hasibuan, Malayu S.P. 2006. Manajemen Dasar, Pengertian, dan ' Masalah,Edisi Revisi. Jakarta : Bum! Aksara

Gardner, Howard. 1993. Multiple Intelligencies. Jakarta :PT Gramedia Pustaka Utama.

Gibson, dkk, 1989. Organisasi Edisi Kelima. Jakarta : PT. Gelora Aksara

Pratama Gie,The Liang .1998. Ensiklopedia Administrasi. Jakarta: Gunung

Agung. Ghozali, Imam. 2005. Aplikasi Analisis Multivariate dengan program SPSS. Semarang : Badan Penerbit Universitas Diponegoro. Hadi, Sutrisno,2007.Analisis Regresi.

Yogyakarta: Andi Offset Handayaningrat. 1989. Manajemen Konflik. Jakarta : PT. 
Gramedia Pustaka Utama. Handoko, T.H. 1992. Manajemen Personalia dan Sumber Daya Manusia. Edisi Kedua. Yogyakarta: BPFE UGM. Husein Umar, 2004, Metode Penelitian Untuk Skripsi Dan Tests Bisnis, Cet ke 6.Jakarta : PT RajaGrafmdo

Persada. Ibnu Hadjar. 1996. Dasar-dasar Metodologi Penelitian Kwantitatif dalam Pendidikan. Jakarta: Raja Grafindo

Persada. Ivancevich, Konopaske, dan Matteson. 2007.Perilaku dan ManajemenOrganisasi, Edisi Ketujuh. Jakarta: Erlangga. Luthans, Fred. 2006.Perilaku Organisasi, (Alih Bahasa

V.A Yuwono, dkk),Edisi Bahasa Indonesia. Yogyakarta:

ANDI. Marzuki.1981. Pengorganisasian. Yogyakarta : Andi Offset. 2005. Metodologi riset. Yogyakarta: Ekonisia.

Moenir, A.S. 2002. Manajemen Pelayanan Umum di Indonesia. Jakarta : Bumi Aksara.

Taliziduhu.2003.5wdqya Organisasi. Jakarta : Rineke cipta. .2003. Kybernology (Ilmu Pemerintahan Baru) 1. Jakarta : Rineka cipta.

Pasolong, Harbani. 2007. Teori Administrasi Publik. Bandung: Alfabeta Porter. L. W., R. M. Steers, R. T. Mowday., and P. V. Boulin. 1974. "Organizational Commitment, Job Satisfaction and Turnover Among Psychiatric Technicians" Journal of Applied Psycology.

Ranupandojo, H., dan Suad Husnan, 1984, Manajemen Personalia, Edisi III, Yogyakarta: BPFE.

Robbins, 2003 dalam Koesmono, Teman, 2007, "Pengaruh Kepemimpinan Dan Tuntutan Tugas Terhadap Komitmen Organisasi Dengan Variabel Moderasi Motivasi Perawat Rumah Sakit Swasta Surabaya", Jurnal Manajemen Dan Kewirausahaan, Universitas Kristen Petra Surabaya Robbins dalam Tika, P. 2008. Budaya Organisasi dan Peningkatan Kinerja Perusahaan. Jakarta: Bumi Aksara.

Robbins, Stephen P, 2003. Perilaku Organisasi, Jilid 2, Jakarta: PT. Indeks Kelompok Gramedia.

Sastrohadiwiryo, B. S. ( 2005 ). Manajemen Tenaga Kerja Indonesia Administratif dan Operasional, Jakarta: Bumi Aksara.

Schuler, R. S., dan Jackson, S.E, (1997), Manajemen Sumber Daya Manusia Menghadapi Abad KE 21, Jakarta : Erlangga. Sergiovanni,

Thomas J et.al.(1987). educational Gonvernance and Administration. New Jersey :Prentice hall inc.

Slamento, Sri (2000). Ilmu organisasi. Surakarta:UNS Press. Sondang P. Siagian .1983 .organisasi 
Soegiarto, $\quad$ Soekidjan, Sp. K.J. (2009)), Komitmen Organisasi Sudahkah Menjadi Bagian Dari Kita.

Sugiyono.2011. Metode Penelitian Kuantitatif Kualitatif \& RND. Bandung : Alfabeta. Sugiyono. 2Q\2Metode Penelitian Bisnis. Bandung:

Alfabeta. Syafi'ie, Inu Kencana. 2002. Kepemimpinan pemerintahan Indonesia. Bandung : PT. Refika Utama.

Syamsi, Ibnu. (1994). Pokok-Pokok Organisasi dan Manajemen. Jakarta: Rineka Cipta. Umar, Husein. 2003. Metode Riset Perilaku Organisasi. Jakarta : Gramedia Veithzal, Rivai. 2004. Manajemen Sumber Daya Manusia Untuk Perusahaan. Cetakan Pertama. JakartarPT. Raja Grafmdo. Welsch, H.P dan La Van, H. 1981

Widiyanto, Joko. 2010. SPSS for Windows Untuk Analisis Data Statistik dan Penelitian. Surakarta: BP-FKIP VMS. Wiryo Kusuma, Iskandar.1982. Masalah Pendidikan Di Masa Mendatang Jakarta: Rajawali. 